\title{
Effect of Global Warming Scenarios on Carotenoid Pigments Gracilaria changii
}

\author{
Nur Indah Sari Arbit ${ }^{* 1,2,3}$, Sharifuddin Bin Andy Omar', Ambo Tuwo ${ }^{3,4}$ \& \\ Eddy Soekendarsi ${ }^{5}$
}

\author{
${ }^{* 1}$ Doctoral Program of Agricultural Science, Hasanuddin University, Makassar, Indonesia. \\ ${ }^{2}$ Faculty of Animal Husbandry and aquaculture, Sulawesi Barat University, Majene, Indonesia. \\ ${ }^{3}$ Center of Excellent for Development and Utilization of Seaweed, Hasanuddin University, Makassar, Indonesia. \\ ${ }^{4}$ Faculty of Marine Science and Fisheries, Has anuddin University, Makassar, Indonesia. \\ ${ }^{5}$ Faculty of Mathematic and Science, Hasanuddin University, Makassar, Indonesia. \\ *Corresponding author: indaharbit@unsulbar.ac.id
}

\begin{abstract}
The phenomenon of global warming is an increase in the earth's temperature due to the greenhouse effect where $50 \%$ of the main contributors to the greenhouse effect are carbon dioxide $\left(\mathrm{CO}_{2}\right)$. Carbon dioxide is one of the ingredients needed for photosynthesis. Photosynthesis is carried out by plants that have chloroplasts. Plants in the waters are Seaweed. Gracilaria changii is a type of red seaweed (Rhodophyceae). The dominant pigment from Gracilaria changii is carotenoids. Carotenoid serves as a light energy absorbent for photosynthesis and serves to protect chlorophyll from light damage. Seeing the important role of carotenoids in Gracilaria changii so that this study aims to determine the effect of increasing temperature and carbon dioxide on carotenoid pigments. Research on the scenario of global warming in this region was first carried out on a laboratory scale, many previous studies were carried out in the cultivation area. This study was conducted for 40 days, seaweed that has been cleaned is put into an aquarium and given an injection of $\mathrm{CO}_{2}$. We were exposed to present-day control seawater (400 ppm $\mathrm{pCO}_{2}$ ) and seawater treated with $\mathrm{CO}_{2}$ to simulate ocean conditions predicted for the next 50-100 years (700 ppm, $1000 \mathrm{ppm}$, and $1300 \mathrm{ppm})$ and temperature treatment $\left(30^{\circ} \mathrm{C}, 32^{\circ} \mathrm{C}\right.$, $34^{\circ} \mathrm{C}$ ). The research design applied in this study is a Completely Randomized Design consisting of nine treatments with three replications. Data analysis used is Analysis of Variance (ANOVA) continued by Post hoc Test. The results obtained from this study there were significant differences $(P<0.05)$ of carbon treatment in carotenoid pigments. The highest carotenoid pigments are found in 700 ppm $\mathrm{CO}_{2}$ injection treatment.
\end{abstract}

Keywords- $\mathrm{CO}_{2}$, Global warming, Gracilaria changii, pigment carotenoids, Temperature

\section{INTRODUCTION}

Global warming is an increase in earth temperature due to the greenhouse effect, which is $50 \%$ caused by Carbon dioxide $\left(\mathrm{CO}_{2}\right)$ (Prasad et al. 2017; Forster, P., et al. 2007). So that this phenomenon has a major impact on living things and the environment (Fabry et al. 2008). The high $\mathrm{CO}_{2}$ in the atmosphere will diffuse into the seawaters and cause chemical changes so that it makes the ocean acidic (Auerbachu et al. 1997). The absorption of carbon dioxide is indicated to cause a reduction of 0.1 units of sea surface $\mathrm{pH}$ which is equivalent to a $30 \%$ increase in the concentration of hydrogen ions in the sea (Caldeira, et.al 2005 ) so that it can cause ocean acidification (Doney et al. 2009).

Carbon dioxide is one of the materials in the process of photosynthesis by plants that have chloroplasts (Joseph et al, 1982; Richter 2018). One of the plants that live in waters is seaweed. Based on the pigment seaweed is divided into 3 major classes namely red seaweed (Rodophyceae), green seaweed (Chlorophyceae), and brown seaweed (Phaeophyceae) (Aryee et al. 2018).

Gracilaria changii is a type of red seaweed (Rhodophyceae) with carotenoids as the dominant pigment (Chan \& Matanjun, 2016). Seaweed is resistant to environmental conditions compared to other types of grass (Wei et al. 2015).

The colors produced by carotenoids range from pale yellow, bright orange, to deep red, depending on the chemical structure of each. Carotenoid functions as an absorbent light energy for photosynthesis and functions to protect chlorophyll from $\mathrm{O} 2$ damage caused by oxidation when the radiation level is high (Richter 2018).

Based on the fact that there is an association between carotenoids and $\mathrm{CO}_{2}$, this study was conducted to determine the effect of increasing carbon dioxide and temperature on the amount of carotenoid pigments. Research on the scenario of global warming in this region was first carried out on a laboratory scale, many previous studies were carried out in the cultivation area. 


\section{METHODS AND MATERIAL}

Gracilariia changii samples were obtained from cultivation sites in Ujung Baji Village, Takalar Regency, Indonesia.
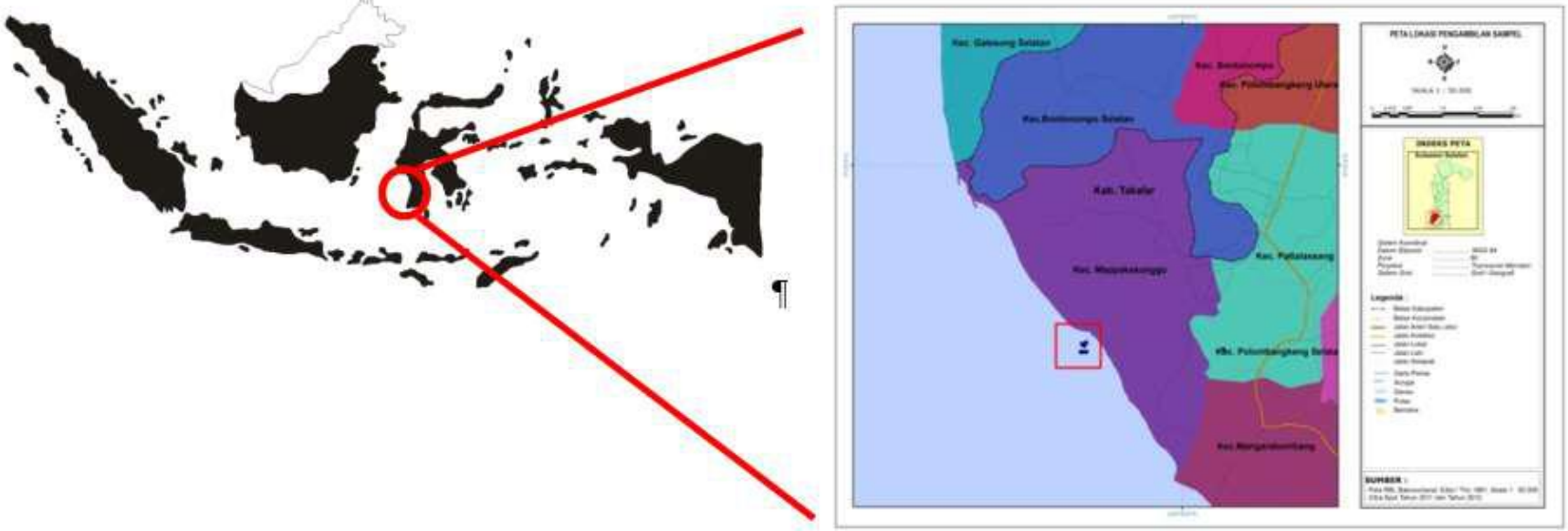

Fig.1: Research Location Map

Sumber: http://www.forumindonesiamuda.org/regional/peta-indonesia

The scenario of global warming is carried out in the Wet Laboratory of the Center for Science and Technology, the Development of Seaweed Research and pigment analys is carried out at the Faculty of Marine and Fisheries Laboratory, Hasanuddin University.

Gracilaria changii of $126 \mathrm{gr}$ seaweed that has been cleaned is put into the aquarium $(60 \times 35 \times 30) \mathrm{cm}$ with a carbon system. The carbon system is used for global warming scenarios and the use of LED lights to optimize photosynthesis (Kim et al. 2015). The aquarium is under the illumination of LED lights on photoperiod $24 \mathrm{~L}$ and it is treated with $\mathrm{CO}_{2}$ and temperature for 40 days.

Atmospheric $\mathrm{CO}_{2}$ amounted to $380 \mathrm{ppm}$ in 2007, increasing by an average of $0.5 \%$ per year and in a decade there will be an increase of $15 \mathrm{ppm}$ so that the atmosphere ranges from 400 ppm in 2018 (Gattuso \& Lavigne, 2009; Watson et al. 2012). Treatment of seawater for injection of $\mathrm{CO}_{2}$ (1) control current time $400 \mathrm{ppm}$ (2) low $700 \mathrm{ppm}$ (3) Medium $1000 \mathrm{ppm}$ (4) Height $1300 \mathrm{ppm}$ and temperature treatment (1) T0 Control $28^{\circ} \mathrm{C}$, (2) $\mathrm{T} 230^{\circ} \mathrm{C}$, (3) $\mathrm{T} 332{ }^{\circ} \mathrm{C}$ (4) T4 $34{ }^{\circ} \mathrm{C}$. Consistent with predictions of ocean warming for the tropics (Poloczanska, E.S. et al, 2007). The research design applied in this study is a Completely Randomized Design consisting of nine treatments with each of three replications. Seawater parameters are shown in table 1.

Table.1: Seawater parameters

\begin{tabular}{|c|c|c|c|c|c|c|c|}
\hline Treatment & $\begin{array}{c}\text { Temperature } \\
\left({ }^{\circ} \mathrm{C}\right)\end{array}$ & Replicate & $\mathrm{pH}$ & Salinity & DO & $\begin{array}{l}p \mathrm{CO}_{2} \\
(\mathrm{ppm})\end{array}$ & $\mathrm{CO}_{2}$ \\
\hline Control $p \mathrm{CO}_{2}$ and $\mathrm{T} 0$ & 28.0 & 3 & $7.94 \pm 0.17$ & $36.67 \pm 6.00$ & $5.20 \pm 2.00$ & 400 & $28,09 \pm 3,99$ \\
\hline Low $p \mathrm{CO}_{2}$ and $\mathrm{T} 1$ & 30.0 & 3 & $7.68 \pm 2.78$ & $37.00 \pm 6.08$ & $6.00 \pm 2.66$ & 700 & $59,12 \pm 3,61$ \\
\hline Low $p \mathrm{CO}_{2}$ and $\mathrm{T} 2$ & 32.0 & 3 & $7.68 \pm 2.78$ & $37.00 \pm 6.08$ & $4.73 \pm 2.41$ & 700 & $57,64 \pm 3,03$ \\
\hline Low $p \mathrm{CO}_{2}$ and $\mathrm{T} 3$ & 34.0 & 3 & $7.85 \pm 2.80$ & $37.67 \pm 6.16$ & $4.10 \pm 2.26$ & 700 & $55,26 \pm 3,04$ \\
\hline Medium $p \mathrm{CO}_{2}$ and $\mathrm{T} 1$ & 30.0 & 3 & $7.24 \pm 2.70$ & $36.67 \pm 6.08$ & $4.60 \pm 2.26$ & 1000 & $51.93 \pm 2.63$ \\
\hline Medium $p \mathrm{CO}_{2}$ and T2 & 32.0 & 3 & $7.01 \pm 2.65$ & $37.00 \pm 6.00$ & $4.90 \pm 1.87$ & 1000 & $61.26 \pm 1.52$ \\
\hline Medium $p \mathrm{CO}_{2}$ and T3 & 34.0 & 3 & $6.87 \pm 2.65$ & $36.67 \pm 6.08$ & $4.50 \pm 1.97$ & 1000 & $79.94 \pm 3.72$ \\
\hline Height $p \mathrm{CO}_{2}$ and $\mathrm{T} 1$ & 30.0 & 3 & $6.29 \pm 2.51$ & $36.00 \pm 6.00$ & $4.93 \pm 2.14$ & 1300 & $105.87 \pm 5,72$ \\
\hline Height $p \mathrm{CO}_{2}$ and $\mathrm{T} 2$ & 32.0 & 3 & $6.44 \pm 2.52$ & $37.00 \pm 6.82$ & $4.67 \pm 2.21$ & 1300 & $109.20 \pm 4.83$ \\
\hline Height $p \mathrm{CO}_{2}$ and T3 & 34.0 & 3 & $6.31 \pm 2.52$ & $36.67 \pm 6.08$ & $4.57 \pm 2.19$ & 1300 & $145.15 \pm 7.06$ \\
\hline
\end{tabular}

The research sample was dried using an oven with a temperature of $50{ }^{\circ} \mathrm{C}$. Then take 2 grams and add $10 \mathrm{ml}$ acetone, let stand for a day in a dark room. After that, absorbance is measured using a spectrophotometer. Measurement of carotenoids with a wavelength of 470 uses formula (De Carvalho et al., 2012): Carotenoids $(\mu \mathrm{g} / \mathrm{g})=[\mathrm{A} \times \mathrm{v}(\mathrm{mL}) \times 104] / \mathrm{A} 1 \% \mathrm{x} \mathrm{w}(\mathrm{g})$, where $\mathrm{A}=$ absorbance; $\mathrm{v}=$ total volume of extract; $\mathrm{w}=$ sample weight; $A 1 \%=2600$ (coefficient of $\beta$-carotene in hexane). 
Data analysis used is Analysis of Variance (ANOVA) followed by Post hoc Test.

\section{RESULTS AND DISCUSSION}

Based on statistical analysis with ANOVA the initial carotenoid pigment content of $0.24 \pm 0.51 \mu \mathrm{g} / \mathrm{g}$ showed a significant $(\mathrm{P}<0.05)$ difference in the content of late carotenoid pigments. At the end of the study the highest carotenoid pigment was found in the injection treatment of $\mathrm{pCO}_{2} 700 \mathrm{ppm}$ with a temperature of $34{ }^{\circ} \mathrm{C}$ having a pigment content of $2.05 \pm 1.32 \mu \mathrm{g} / \mathrm{g}$ followed by a temperature of $32{ }^{\circ} \mathrm{C}$ with a pigment content of $1.66 \pm 1.28$ $\mu \mathrm{g} / \mathrm{g}$ and temperature $30^{\circ} \mathrm{C}$ has a pigment content of 1.66 $\pm 1.43 \mu \mathrm{g} / \mathrm{g}$. The carotenoid pigment content at injection of $p \mathrm{CO}_{2} 1000 \mathrm{ppm}$ with a temperature of $32{ }^{\circ} \mathrm{C}$ was 1.34 $\pm 1.04 \mu \mathrm{g} / \mathrm{g}$ whereas at $34{ }^{\circ} \mathrm{C}$ the carotenoid pigment content was $1.26 \pm 1.24 \mu \mathrm{g} / \mathrm{g}$ and at a temperature of 30 ${ }^{\circ} \mathrm{C}$ the carotenoid pigment content amounting to $1.22 \pm$ $0.79 \mu \mathrm{g} / \mathrm{g} . p \mathrm{CO}_{2} 1300 \mathrm{ppm}$ at $30{ }^{\circ} \mathrm{C}$ has a pigment content of $0.94 \pm 0.91 \mu \mathrm{g} / \mathrm{g}$, the pigment content at $34{ }^{\circ} \mathrm{C}$ is $0.91 \pm 0.86 \mu \mathrm{g} / \mathrm{g}$, and at $32{ }^{\circ} \mathrm{C}$ has a pigment content of $0.73 \pm 0.86 \mu \mathrm{g} / \mathrm{g}$. The carotenoid pigment content at the end of the study showed that injection of $p \mathrm{CO}_{2} 700 \mathrm{ppm}$ had a significant difference $(\mathrm{p}<0.05)$ for injection of $p \mathrm{CO}_{2}$ $1000 \mathrm{ppm}$ and injection of $p \mathrm{CO}_{2} 1300 \mathrm{ppm}$. Variations in carotenoid pigment content in this research experiment are shown in Figure 2.

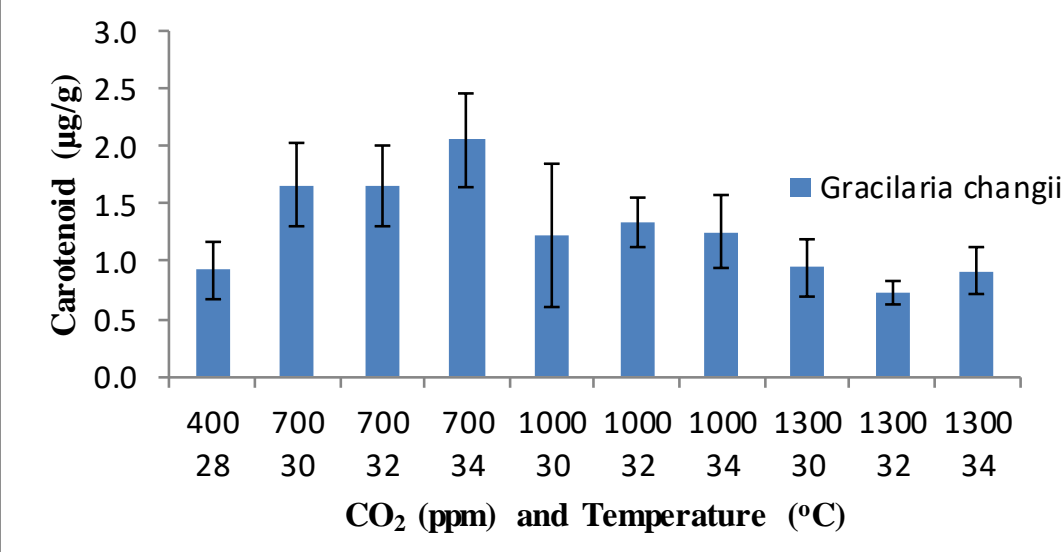

Fig.2: Carotenoid pigments in carbon sequestration treatment

This study showed an increase in the amount of carotenoid pigment Gracilaria changii after being given the addition of $\mathrm{CO}_{2}$ and temperature. During the experiment, the control experienced an increase in pigment levels when compared with the initial levels of the sample before the experiment was carried out. The level of carotenoid pigment increases with the addition of $p \mathrm{CO}_{2} 700 \mathrm{ppm}$ and then decreases slightly with the addition of $1000 \mathrm{ppm}$ $p \mathrm{CO}_{2}$. The carotenoid pigment content at the addition of $p \mathrm{CO}_{2} 1300 \mathrm{ppm}$ has decreased and returned to the same as the control but the carotenoid pigment levels have all increased when compared to the initial pigment of the study.

Carotenoid pigments are one of the pigments found in chloroplasts which play a role in photosynthesis (Salisbury, F. B. \& Cleon, W. R., -). Photosynthesis is the process of compiling organic compounds from $\mathrm{CO}_{2}$ and Water that require light (Loveless, A.R., 1991). Light is very closely related to chloroplasts because light has the nature of wavelengths and properties of particles which are energy. The chloroplast pigment absorbs more than $90 \%$ of the purple and blue wavelengths that hit it and is almost as big as the percentage of orange and red wavelengths (Loveless, A.R., 1991).
Addition of carbon dioxide concentration to $700 \mathrm{ppm}$ and supported by photoperiod $24 \mathrm{~L}$ caused an increase in photosynthesis (Loveless, A.R., 1991). This is because Gracilaria changii will take more carbon dioxide because the Rubisco enzyme that functions to hold $\mathrm{CO}_{2}$ becomes active in the presence of light (Caemmere, S Von; G.D. 1981; Salisbury, F. B. \& Cleon, W. R., -). The temperature of $34{ }^{\circ} \mathrm{C}$ is the optimum temperature in the tropics for increasing the speed of photosynthesis. Temperatures above about $35{ }^{\circ} \mathrm{C}$ cause temporary damage or permanent damage to the protoplasm, which causes a decrease in the speed of photosynthesis (Loveless, A.R., 1991).

At the end of the study the addition of $p \mathrm{CO}_{2}$ of $1000 \mathrm{ppm}$ and $p \mathrm{CO}_{2}$ of $1300 \mathrm{ppm}$ showed an increase in carotenoid pigment content when compared with the levels of carotenoid pigments at the beginning of the study, but rather decreased compared to the addition of $p \mathrm{CO}_{2} 700$ ppm due to the high addition of carbon dioxide can affect $\mathrm{pH}$ levels in water. Low $\mathrm{pH}$ in water makes work function Rubisco enzymes found in inactive chloroplasts and decreases in $\mathrm{pH}$ greatly influence the transfer of electrons from polypeptides with molecular weights around $33 \mathrm{kDa}$ to P680 (Conjeaud 1980; Salisbury, F. B. \& Cleon, W. R., -). 


\section{CONCLUSIONS}

The conclusion of this study:

1. shows effect of the scenario of global warming on carotenoid pigment.

2. Treatment of carbon dioxide injection and temperature differences indicate an increase in amount of carotenoid pigments and the highest increase occurs in the injection of carbon dioxide $700 \mathrm{ppm}$ with a pigment content of $2.05 \pm$ $1.32 \mu \mathrm{g} / \mathrm{g}$.

\section{ACKNOWLEDGEMENTS}

We would like to thank to Center of Excellent for Development and Utilization of Seaweed, Hasanuddin University, Makassar, Indonesia, for the use of laboratory equipment and aquarium space and Dr. Inayah yasir, M.Sc for helpful comments on the manuscript.

\section{REFERENCES}

[1] Aryee, A.N.A., Agyei, D. \& Akanbi, T.O., 2018. Recovery an Utilization of Seaweed Pigmentsin Food Processing. Current Opinion in Food Science. Available at:https://doi.org/10.1016/j.cofs.2018.03.013.

[2] Auerbachu, D.I. et al., 1997. Impacts of ocean $\mathrm{CO}_{2}$ disposal on marine life: I . A toxicological assessment integrating constant concentration laboratory assay data with variable concentration field exposure. Environmental Modeling and Assessment 2, (December), pp.333-343.

[3] Berry, J. A.; Downton, W.J.S., 1982. Environmental Regulation of Photosynthesis, Academic Press, Inc.

[4] Caemmere, S Von; G.D., F., 1981. Some Relationship Between the Biochemistry of Photosynthesis and the Gas Exchange of Leaves. Planta, pp.1-2.

[5] Caldeira, Ken; Elderfield, Harry; Guldberg, Ove Hoegh; Liss, Peter; Riebesell Ulf; Shepherd, John; Turley, Carol; Watson, A., 2005. Ocean acidification due to increasing U. The Clyvedon Press Ltd, Cardiff, ed., London: The Royal Society.

[6] De Carvalho, L.M.J. et al., 2012. Total carotenoid content , $\alpha$-carotene and $\beta$-carotene, of landrace pumpkins ( Cucurbita moschata Duch ): A preliminary study. FRIN, 47(2), pp.337-340. Available at: http://dx.doi.org/10.1016/j.foodres.2011.07.040.

[7] Chan, P.T. \& Matanjun, P., 2016. Chemical composition and physicochemical properties of tropical red seaweed, Gracilaria changii. Food Chemistry.

Available.doi.org/10.1016/j.foodchem. 2016.10.066.

[8] Conjeaud, H.P.M., 1980. The Effect of $\mathrm{pH}$ on the
Reduction Kinetics of P-680 in Tris-Treated Chloroplasts. Biochimica et Biophysica Acta, 590, pp.353-359.

[9] Doney, S.C. et al., 2009. Ocean Acidification: The Other CO 2 Problem. Annual Review of Marine Science, 1, pp.92-169.

[10] Fabry, V.J. et al., 2008. Impacts of ocean acidification on marine fauna and ecosystem processes., (Dic), pp.414-432.

[11] Forster, Piers; Venkatachalam, R., 2007. Changes in Atmospheric Constituents and in Radiative Forcing. In R. Nakajima, Teruyuki; Veerabhadran, ed. Changes in Atmospheric Constituents and in Radiative Forcing. New York: Cambridge University Press, pp. 130-234.

[12] Gattuso, J.\& Lavigne, 2009. Photosynthesis and Calcification at Cellular Organisme and Community levels in Coral Reefs: a Review on Interactions and Control by Carbonat Chemistry. American Zoologyst, 39: 160-83.

[13] Kim, J.K. et al., 2015. Growth and pigment content of Gracilaria tikvahiae McLachlan under fl uorescent and LED lighting. Aquaculture, 436, pp.52-57. Available at: ttp://dx.doi.org/10.1016/j.aquaculture.2014.10.037.

[14] Loveless, A.R., 1991. Prinsip-Prinsip Biologi Tumbuhan untuk Daerah Tropik. Jilid 1., PT Gramedia Pustaka Utama: jakarta.

[15] Poloczanska, E.S.; Babcock, R.C; Butler, A.; Hobday, A.J.; Hoegh- Guldberg, O.; Kunz, T. J.; Matear, R.; Milton, D.A; Okey, T.A. \& Richardson, A.J., 2007. Climate Change and Australian Marine Life. Oceanography and Marine Biology:An Annual Review, 45(June), pp.407-478.

[16] Prasad, P.V. V, Thomas, J.M.G. \& Narayanan, S., 2017. Global Warming Effects Second Edition., Elsevier. Available at: http://dx.doi.org/10.1016/B978-0-12-3948076.00013-7.

[17] Richter, P.D.H., 2018. Pigments Friedrich, ed., Alexander University, Erlangen Nurnberg, Germany: Elsevier Inc.

[18] Salisbury, F. B. \& Cleon, W. R., -. Fisiologi Tumbuhan. Jilid 2: ITB Bandung.

[19] Watson, S. et al., 2012. Ocean acidification and warming reduce juvenile survival of the fluted giant clam, Tridacna squamosa., 32(3), pp.177-180.

[20] Wei, L. et al., 2015. Micropropagation and protein profile analysis by SDS-PAGE of Gracilaria changii ( Rhodophyta , Solieriaceae ). Aquaculture Reports, 1, pp.10-14. Available. doi.org/10.1016/j.aqrep.2015.03.002. 